\author{
Marquette University \\ e-Publications@Marquette
}

$12-2013$

\title{
Using Resonance Raman Cross-section Data to Estimate the Spin State Populations of Cytochromes P450
}

Piotr J. Mak

Marquette University, piotr.mak@marquette.edu

Qianhong Zhu

Marquette University

James R. Kincaid

Marquette University, james.kincaid@marquette.edu

Follow this and additional works at: https://epublications.marquette.edu/chem_fac

Part of the Chemistry Commons

\section{Recommended Citation}

Mak, Piotr J.; Zhu, Qianhong; and Kincaid, James R., "Using Resonance Raman Cross-section Data to Estimate the Spin State Populations of Cytochromes P450" (2013). Chemistry Faculty Research and Publications. 397.

https://epublications.marquette.edu/chem_fac/397 


\title{
Using Resonance Raman Cross- section Data to Estimate the Spin State Populations of Cytochromes $\mathrm{P} 450$
}

\author{
Piotr J. Mak \\ Department of Chemistry, Marquette University \\ Milwaukee, WI \\ Qianhong Zhu \\ Department of Chemistry, Marquette University \\ Milwaukee, WI \\ James R. Kincaid \\ Department of Chemistry, Marquette University \\ Milwaukee, WI
}

\begin{abstract}
:
The cytochromes P450 (CYPs) are heme proteins responsible for the oxidation of xenobiotics and pharmaceuticals and the biosynthesis of essential steroid products. In all cases, substrate binding initiates the enzymatic cycle, converting ferric low spin (LS) to high-spin (HS), with the efficiency of the conversion varying widely for different substrates, so documentation of this conversion for a given substrate is an important objective. Resonance Raman $(r R)$ spectroscopy can effectively yield distinctive frequencies for the $v_{3}$ "spin state marker" bands. Here, employing a reference cytochrome P450
\end{abstract}

Journal of Raman Spectroscopy, Vol. 44, No. 12 (December 2013): pg. 1792-1794. DOI. This article is @ Wiley and permission has been granted for this version to appear in e-Publications@Marquette. Wiley does not grant permission for this article to be further copied/distributed or hosted elsewhere without the express permission from Wiley. 
NOT THE PUBLISHED VERSION; this is the author's final, peer-reviewed manuscript. The published version may be accessed by following the link in the citation at the bottom of the page.

(CYP101), the intensities of the $\mathrm{V}_{3}$ modes (ILS) and (IHS) relative to an internal standard (sodium sulfate) yield relative populations for the two spin states; i.e., a value of 1.24 was determined for the ratio of the relative cross sections for the $v_{3}$ modes. Use of this value was then shown to permit a reliable calculation of relative populations of the two spin states from rR spectra of several other Cytochromes P450. The importance of this work is that, using this information, it is now possible to conveniently document by $\mathrm{rR}$ the spin state population without conducting separate experiments requiring different analytical methods, instrumentation and additional sample.

Keywords: Cytochrome P450, Raman, spin state.

The cytochromes P450 (CYPs) are heme-based monooxgenases responsible for the oxidative metabolisim of a huge number of relatively inert substrates, including pharmaceuticals and other xenobiotics, and for the biosynthesis of essential steroid products. ${ }^{[1-4]}$ Substrate binding initiates the enzymatic cycle by triggering a crucial low spin (LS) to high spin (HS) state change that facilitates reduction to the ferrous heme intermediate that rapidly binds oxygen, which is then converted to the highly reactive Compound I. ${ }^{[5]}$ Inasmuch as the efficiency of spin state conversion varies widely for different substrates and enzymes, ${ }^{[1,2,6,7]}$ documentation of the extent of this conversion for a given substrate is an important experimental objective. Resonance Raman ( $r R$ ) spectroscopy can effectively document the presence of HS or LS states of the ferric heme by appearance of distinctive frequencies observed at $\sim 1485$ and $1500 \mathrm{~cm}^{-1}$, respectively. ${ }^{[8-10]}$ Given recent advances in producing and stabilizing these extremely important enzymes, ${ }^{[11-13]}$ it is anticipated that applications of $r R$ to these proteins will now expand considerably. The purpose of this work is to provide a systematic approach to utilize rR spectroscopy to reliably estimate spin state populations for different substrate/enzyme combinations.

Cytochrome P450cam (CYP101), an ideal reference protein, exhibits an almost complete spin state conversion upon binding its natural substrate, camphor, switching from $96 \%$ LS to $95 \% \mathrm{HS}$, as documented by electronic absorption spectrophotometry, Fig. S1 (Supporting Information). ${ }^{[14]}$ The CYP101 was expressed and purified as published earlier; ${ }^{[11,15]}$ experimental procedures, including sample preparation for rR measurements, are presented in Supporting

Journal of Raman Spectroscopy, Vol. 44, No. 12 (December 2013): pg. 1792-1794. DOI. This article is (C) Wiley and permission has been granted for this version to appear in e-Publications@Marquette. Wiley does not grant permission for this article to be further copied/distributed or hosted elsewhere without the express permission from Wiley. 
Information. The laser excitation lines for these studies were 406.7 and $413.1 \mathrm{~nm} \cdot{ }^{[8-10,16-19]}$

As shown in Figure 1, the spin state change is observed as a shift of $v_{3}$ from $1502 \mathrm{~cm}^{-1}$ (LS) to $1488 \mathrm{~cm}^{-1}$ (HS). To estimate relative rR cross sections for the substrate-free (SF) and substrate-bound (SB) samples, three samples of these two forms, each containing $0.500 \mathrm{M}$ internal standard $\mathrm{Na}_{2} \mathrm{SO}_{4}$, were measured and their spectra were analyzed using the following peak fitting procedure. The $\mathrm{SO}_{4}{ }^{2-}$ bands at $981 \mathrm{~cm}^{-1}$ (and all heme modes) were found to fit best with a 30\% Gaussian/ $70 \%$ Lorentzian function. The average band width for the sulfate mode for all six spectra was $10.1 \mathrm{~cm}^{-1}$; the resulting band widths of the spin-marker bands were $11.5 \mathrm{~cm}^{-1}\left(1488 \mathrm{~cm}^{-1}\right)$ and 11.3 $\mathrm{cm}^{-1}\left(1502 \mathrm{~cm}^{-1}\right)$. Peak areas, instead of peak heights, were used to calculate the relative cross sections of the spin state marker bands; i.e., $\mathrm{I}_{\mathrm{LS}} / \mathrm{I}_{\mathrm{IS}}$ and $\mathrm{I}_{\mathrm{HS}} / \mathrm{I}_{\mathrm{IS}}$, where $\mathrm{I}_{\mathrm{IS}}$ is the intensity of the $981 \mathrm{~cm}^{-1}$ band of sulfate. Noting that SF CYP101 is $96 \%$ low spin and the camphorbound is $95 \%$ high spin, ${ }^{[14]}$ the operative relative intensities, $Y_{L S}$ and $\mathrm{Y}_{\mathrm{HS}}$, values were derived by dividing the raw relative intensities by 0.96 and 0.95 factors, respectively. The $\mathrm{Y}_{\mathrm{HS}} / \mathrm{Y}_{\mathrm{LS}}$ ratios of the $\mathrm{v}_{3}$ bands were calculated for all nine combinations derived from six samples and the results are presented in Table S1 of Supporting Information. The $\mathrm{Y}_{\mathrm{HS}} / \mathrm{Y}_{\mathrm{LS}}$ ratio for the $\mathrm{V}_{3}$ mode with $406.7 \mathrm{~nm}$ excitation line is $1.24 \pm$ 0.06 ; similar calculations for spectra measured with the $413.1 \mathrm{~nm}$ excitation line yielded a $\mathrm{Y}_{\mathrm{HS}} / \mathrm{Y}_{\mathrm{LS}}$ ratio of $1.19 \pm 0.04$. Though of borderline significance, this smaller value is reasonable, because the $413.1 \mathrm{~nm}$ line is closer to resonance with the Soret band of the LS sample (417 nm) (Table S1, Supporting Information).

Journal of Raman Spectroscopy, Vol. 44, No. 12 (December 2013): pg. 1792-1794. DOI. This article is (C Wiley and permission has been granted for this version to appear in e-Publications@Marquette. Wiley does not grant permission for this article to be further copied/distributed or hosted elsewhere without the express permission from Wiley. 
NOT THE PUBLISHED VERSION; this is the author's final, peer-reviewed manuscript. The published version may be accessed by following the link in the citation at the bottom of the page.

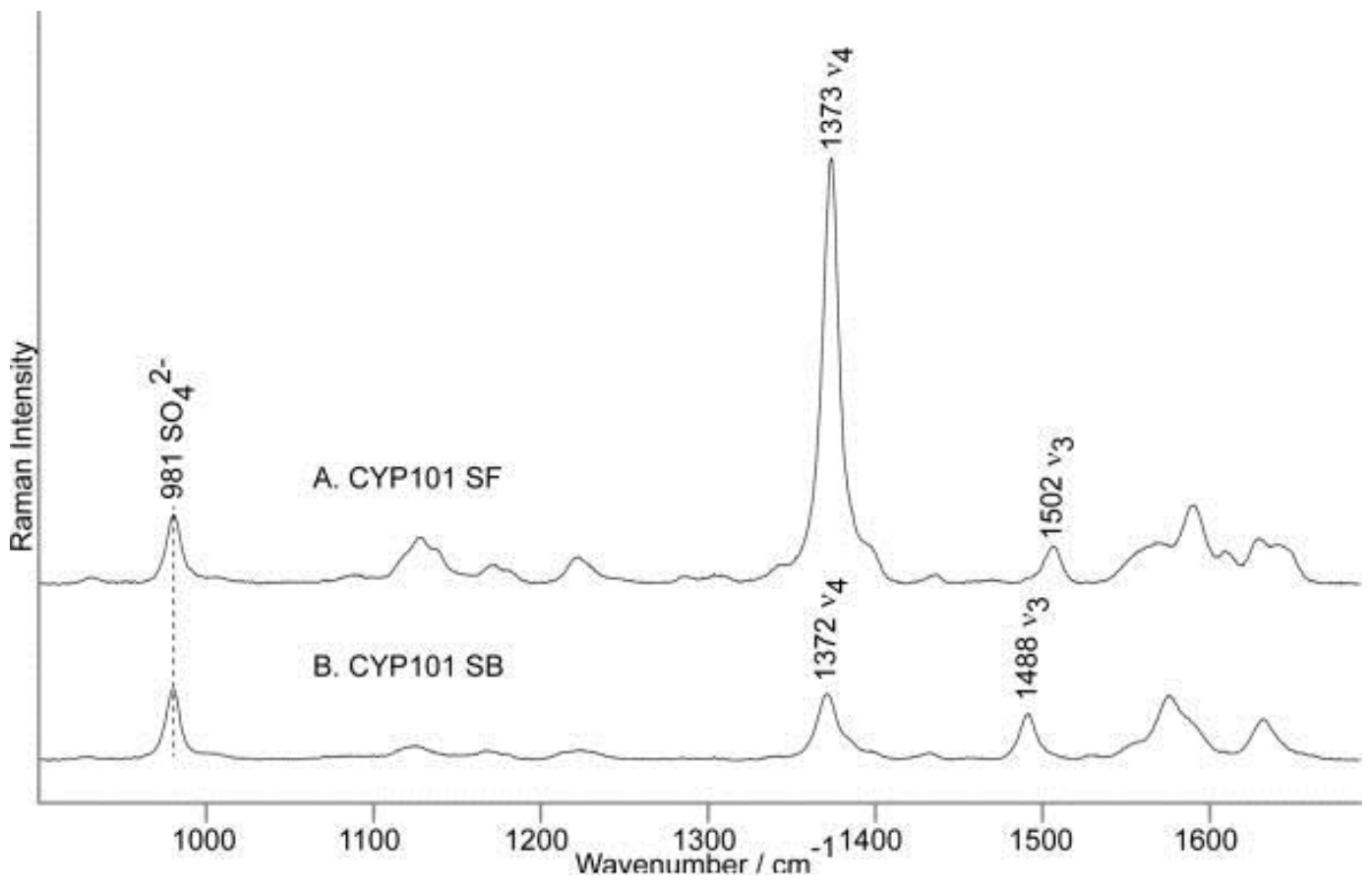

Figure 1 The resonance Raman spectra of ferric CYP101 substrate-free (A) and substrate-bound (B). Spectra measured with $406.7 \mathrm{~nm}$ excitation line and normalized to the sulfate band at $981 \mathrm{~cm}^{-1}$.

In order to expand potential applications of this procedure, these ratios were also calculated for the $v_{4}$ and $v_{7}$ modes with both excitation lines (Table S2, Supporting Information). These data can be used to normalize spectra in different regions. One can apply the $\mathrm{Y}_{\mathrm{HS}} / \mathrm{Y}_{\mathrm{LS}}$ ratio of $0.21 \pm 0.013$ for the intense $\mathrm{V}_{4}$ mode when normalizing high frequency spectra (Fig. S2, Supporting Information) and in the low frequency region one could utilize the $0.38 \pm 0.020$ ratio for $v_{7}$ mode.

Given that the electronic spectra of both the HS and LS states of the bacterial CYPs correspond well with those of mammalian CYPs, ${ }^{[20]}$ it is reasonable to expect that the value of 1.24 derived here for CYP101 should be valid for spectra of mammalian CYPs. To evaluate this issue, the derived 1.24 value was applied to calculate the percentage of spin state conversion upon substrate binding of several mammalian cytochromes available in our laboratory; i.e., CYP2B4, ND:CYP3A4 and ND:CYP17. ${ }^{[21-25]}$ The percentages of LS and HS states calculated from rR spectra ( $406.7 \mathrm{~nm}$ excitation) using the method presented above were compared with percentages independently derived from available UV-Vis data (Table1). As can be seen, the data match quite well for CYP2B4 with butylated hydroxytoluene (BHT),

Journal of Raman Spectroscopy, Vol. 44, No. 12 (December 2013): pg. 1792-1794. DOI. This article is (C) Wiley and permission has been granted for this version to appear in e-Publications@Marquette. Wiley does not grant permission for this article to be further copied/distributed or hosted elsewhere without the express permission from Wiley. 
CYP3A4 both SF and with erythromycin (ERY) as well as CYP17 with progesterone (PROG) and 17-hydroxyprogesterone (17-OH PROG). The value obtained here for the testosterone (TST)-bound ND:CYP3A4 falls within the range reported for measurements with UV-visible spectrophotometry; as is discussed more thoroughly in several earlier works dealing with substrate-binding equilibria and spin state conversion for these systems, ${ }^{[22-24]}$ the percentage $L S \rightarrow$ HS conversion is not linearly related to the number of bound substrates and is further complicated by the fact that substrate access to enzyme also depends on partitioning of the substrate into the lipid bilayer of the nanodisc. Similar complications can also be encountered for the bromocryptine (BC)-bound samples of the ND:CYP3A4 system and may account for the slightly larger, but not unreasonable, discrepancy seen here; i.e., $80 \%$ vs $93 \%$. ${ }^{[26]}$

\begin{tabular}{|c|c|c|c|c|}
\hline \multirow[t]{2}{*}{ protein } & \multicolumn{2}{|c|}{ Resonance Raman } & \multicolumn{2}{|l|}{ UV-Vis } \\
\hline & $\%$ HS & $\%$ LS & $\% \mathrm{HS}$ & $\%$ LS \\
\hline \multicolumn{5}{|l|}{ CYP2B4 } \\
\hline$+\mathrm{BHT}$ & 94 & 6 & $93^{\underline{a}}$ & $7^{\underline{Q}}$ \\
\hline CYP3A4 SF & 5 & 95 & $11^{\underline{b}}$ & $89^{\underline{b}}$ \\
\hline$+\mathrm{TST}$ & 74 & 26 & & $8^{\underline{b}}, \underline{c}$ \\
\hline$+\mathrm{BC}$ & 80 & 20 & & \\
\hline + ERY & 19 & 81 & $22^{\underline{b}}$ & $78^{\underline{\underline{O}}}$ \\
\hline CYP17 & & & & \\
\hline + PROG & 94 & 6 & $97^{\underline{d}}$ & $3^{\underline{d}}$ \\
\hline + 17-OH PROG & 59 & 41 & $62^{\underline{\underline{x}}}$ & $38^{\underline{\underline{x}}}$ \\
\hline
\end{tabular}

Table 1 The calculated percentage of spin state populations in various cytochromes P450 measured with $406.7 \mathrm{~nm}$ excitation line and using the $\mathrm{Y}_{\mathrm{HS}} / \mathrm{Y}_{\mathrm{LS}}$ ratio of 1.24 the $v_{3}$ modes. The calculated data are compared with the data derived from UV-Vis spectra.

${ }^{\text {areference }}{ }^{21}$.

breference 22

Journal of Raman Spectroscopy, Vol. 44, No. 12 (December 2013): pg. 1792-1794. DOI. This article is @ Wiley and permission has been granted for this version to appear in e-Publications@ Marquette. Wiley does not grant permission for this article to be further copied/distributed or hosted elsewhere without the express permission from Wiley. 
NOT THE PUBLISHED VERSION; this is the author's final, peer-reviewed manuscript. The published version may be accessed by following the link in the citation at the bottom of the page.

creference 23

dreference ${ }^{25}$.

\section{Supplementary Material}

\section{Supporting Information}

\section{Using resonance Raman cross-section data to estimate the spin state populations of Cytochromes P450}

Piotr J. Mak, Qianhong Zhu and James R. Kincaid*

Department of Chemistry, Marquette University, Milwaukee WI 53233, USA

E-mail: james.kincaid@marquette.edu

Phone: (414) 2883539

Fax: (414) 2887066

\section{Acknowledgments}

This work was supported in part by grants from the National Institutes of Health (GM96117) and the National Science Foundation (MCB 0951110) to JRK.

\section{Footnotes}

Supporting information

Supporting information may be found in the online version of this article.

\section{References}


NOT THE PUBLISHED VERSION; this is the author's final, peer-reviewed manuscript. The published version may be accessed by following the link in the citation at the bottom of the page.

1. Ortiz de Montellano PR, editor. Cytochrome P450: Structure, Mechanism, and Biochemistry. Kluwer Academic/Plenum Publisher; New York: 2005.

2. Sigel A, Sigel H, Sigel RKO, editors. Metal Ions in Life Sciences. Vol. 3. John Wiley \& Sons, Ltd.; 2007.

3. Guengerich FP. Ann. Rev. Pharmacol. Toxicol. 1999;39:1.

4. Miller WL, Auchus RJ. Endocr. Rev. 2011;32:81.

5. Denisov IG, Makris TM, Sligar SG, Schlichting I. Chem. Rev. 2005; 105:2253.

6. Sligar SG, Gunsalus IC. Proc. Natl. Acad. Sci. U.S.A. 1976;73:1078.

7. Fisher MT, Sligar SG. J. Am. Chem. Soc. 1985;107:5018.

8. Spiro TG, editor. Biological Applicfations of Raman Spectroscopy. John Wiley \& Sons; New York: 1988.

9. Kincaid JR. In: The Porphyrin Handbook. Kadish KM, Smith KM, Guilard R, editors. Vol. 7. Academic Press; 2000. p. 225.

10. Spiro TG, Soldatova AV, Balakrishnan G. Coord. Chem. Rev. 2013;257:511.

11. Sibbesen O, Voss JJ, Ortiz de Montellano PR. J. Biol. Chem. $1996 ; 271: 22462$.

12. Denisov IG, Sligar SG. Biochim. Biophys. Acta. 2011;1814:223.]

13. Denisov IG, Mak PJ, Makris TM, Sligar SG, Kincaid JR. J. Phys. Chem. A. 2008;112:13172.

14. Fisher MT, Sligar SG. Biochemistry. 1985;24:6696.

15. O'Keeffe DH, Ebel RE, Peterson JA. Methods in Enzymology. 1978;52:151.

16. Mak PJ, Kaluka D, Manyumwa EM, Zhang H, Deng T, Kincaid JR. Biopolymers. 2008;89:1045.

17. Wells AV, Li P, Champion PM, Martinis SA, Sligar SG. Biochemistry. $1992 ; 31: 4384$

18. Tosha T, Kagawa N, Arase M, Waterman MR, Kitagawa T. J. Biol. Chem. $2008 ; 283: 3708$.

19. Mak PJ, Denisov IG, Grinkova YV, Sligar SG, Kincaid JR. J. Am. Chem. Soc. $2011 ; 133: 1357$.

20. Sato R, Omura T. Cytochrome P-450. Academic Press; New York: 1978.

Journal of Raman Spectroscopy, Vol. 44, No. 12 (December 2013): pg. 1792-1794. DOI. This article is (c) Wiley and permission has been granted for this version to appear in e-Publications@Marquette. Wiley does not grant permission for this article to be further copied/distributed or hosted elsewhere without the express permission from Wiley. 
NOT THE PUBLISHED VERSION; this is the author's final, peer-reviewed manuscript. The published version may be accessed by following the link in the citation at the bottom of the page.

21. Personal communication. Dr. Sang-Choul Im; Department of Anesthesiology, University of Michigan.

22. Das A, Grinkova YV, Sligar SG. J. Am. Chem. Soc. 2007;129:13778.

23. Frank DJ, Denisov IG, Sligar SG. J. Biol. Chem. 2011;286:5540.

24. Denisov IG, Baas BJ, Grinkova YV, Sligar SG. J. Biol. Chem. $2007 ; 282: 7066$.

25. Personal communication. Michael Gregory, University of Illinois at Urbana Champaign.

26. Nath A, Grinkova YV, Sligar SG, Atkins WM. J. Biol. Chem. $2007 ; 282: 28309$.

\section{About the Authors}

James R. Kincaid : Email: james.kincaid@marquette.edu

Phone: (414) 2883539 Fax: (414) 2883539.

Journal of Raman Spectroscopy, Vol. 44, No. 12 (December 2013): pg. 1792-1794. DOI. This article is @ Wiley and permission has been granted for this version to appear in e-Publications@ Marquette. Wiley does not grant permission for this article to be further copied/distributed or hosted elsewhere without the express permission from Wiley. 